\title{
Dairy herd production aspects of family farms in Western Amazon, Brazil
}

\section{Aspectos produtivos dos rebanhos leiteiros de propriedades agrícolas familiares na Amazônia Ocidental}

\author{
Eduardo Mitke Brandão Reis ${ }^{1 *}$; Marcos Aurélio Lopes ${ }^{2}$; André Luis Ribeiro Lima ${ }^{3}$; \\ Fabiana Alves Demeu ${ }^{4}$; Gideon Carvalho de Benedicto ${ }^{3}$; Renato Mesquita Peixoto ${ }^{5}$; \\ João Paulo Bussons ${ }^{6}$; Camilla Birenbaum Nobile ${ }^{6}$; Luane Pereira Linhares ${ }^{6}$
}

\section{Highlights:}

High-production farms had a production of $1,755.65 \mathrm{~L} \mathrm{ha}^{-1} \mathrm{yr}^{-1}$.

Low-production cluster had a production of $492.75 \mathrm{~L} \mathrm{ha}^{-1} \mathrm{yr}^{-1}$.

Average herd composition was inadequate for the studied farms.

Monthly household income was 97.47 higher in the high-production cluster.

Both groups have often used natural breeding in their reproductive.

\begin{abstract}
This study aimed to evaluate the production parameters of herds in 100 dairy family farms in the mesoregion of the Acre Valley, in Western Amazon, Brazil. To this end, the farms were divided into two levels of milk production. Data were collected from March to June 2016, using a 248-question semistructured form and on-site observations. The information was recorded in SPSS ${ }^{\circledR}$ spreadsheets. Dairy farmers were divided into two clusters known as "high production cluster" $\left(1,755.65 \mathrm{~L} \mathrm{ha}^{-1} \mathrm{yr}^{-1}\right)$ and

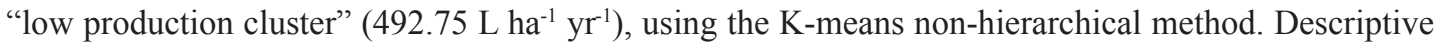
statistics was used and, with the aid of the multivariate cluster analysis, cattle ranchers were divided into the two clusters (high and low production). The results showed that the high-production cluster had larger total milk production ( $\mathrm{L}$ milk cow ${ }^{-1} \mathrm{day}^{-1}$ ) and family income within smaller areas and using less workforce. The farmers in this group also used more ear tags for cattle identification and more technologies such as electric fence and artificial insemination at a fixed time. We concluded that family farms should improve their management and receive technical assistance to strengthen their weaknesses in dairy-cow health and reproduction systems. Moreover, milk yield in these dairy farms should be improved to increase profitability of farmers.
\end{abstract}

Key words: Acre. Dairy farming. Diagnosis. Rural development.

' Prof., Dr., Centro de Ciências Biológicas e da Natureza, Universidade Federal do Acre, UFAC, Rio Branco, AC, Brasil. E-mail: edumitke@gmail.com

2 Prof. Titular, Dr., Universidade Federal de Lavras, UFLA, Departamento de Medicina Veterinária, Lavras, MG, Brasil. E-mail: malopes@dmv.ufla.br

3 Profs. Drs., UFLA, Departamento de Administração e Economia, Lavras, MG, Brasil. E-mail: andreluisnep@yahoo.com.br; gideon.benedicto@dae.ufla.br

4 Prof., Dr., Instituto Federal de Rondônia, IFRO, Ariquemes, RO, Brasil. E-mail: fabiana.alves@ifro.edu.br

5 Dr., Empresa Brasileira de Pesquisa Agropecuária, EMBRAPACAPRINOS E OVINOS, Sobral, CE. Bolsista de Desenvolvimento Científico Regional do Conselho Nacional de Desenvolvimento Científico e Tecnológico (DCR-CNPq/FUNCAP), nível C, Brasília, DF, Brasil. E-mail: renatomiraima@gmail.com

6 Discentes de Mestrado do Programa de Pós-Graduação em Sanidade e Produção Animal Sustentável na Amazônia Ocidental, PPGESPA/UFAC, Acre, AC, Brasil. E-mail: camillabnobile@gmail.com; luanelinharesmv@gmail.com; bussonsj@gmail.com

* Author for correspondence 


\section{Resumo}

O objetivo deste estudo foi analisar 100 fazendas leiteiras sob regime de agricultura familiar a partir da mesorregião do Vale do Acre, na Amazônia Ocidental, Brasil. considerando alguns aspectos dos rebanhos, considerando diferentes níveis de produção de leite. Os dados foram coletados no período de março a junho de 2016, a partir de um formulário semiestruturado, contendo 248 questões, por meio de observação in loco, bem como as respostas obtidas com os proprietários; e gravados em planilhas SPSS $^{\circledR}$. Os produtores de leite foram divididos em agrupamentos denominados "maior produtividade" (1.755,65 litro/hectare/ano) e "menor produtividade" (492,75 litros / hectare / ano) utilizando o método não-hierárquico K-means. Adotou-se a estatística descritiva e, com o auxílio da metodologia de análise multivariada de clusters, os pecuaristas foram divididos em dois agrupamentos com diferentes características em termos de produtividade (maior e menor). Algumas diferenças relevantes entre as propriedades foram identificadas: aquelas pertencentes ao cluster de maior produtividade aumentaram a produção total de leite, leite/vaca/dia e renda familiar, e utilizaram menor área e força de trabalho para produção. Essas propriedades também mostraram maior uso de brincos para identificação e utilizaram mais tecnologias, como cerca elétrica e inseminação artificial em tempo fixo. Concluímos que é necessário melhorar a gestão das propriedades familiares e tomar medidas de assistência técnica para corrigir os pontos fracos na saúde e reprodução das vacas leiteiras. Além disso, é essencial melhorar a produtividade para aumentar a lucratividade das fazendas leiteiras rurais.

Palavras-chave: Acre. Desenvolvimento rural. Diagnóstio. Pecuária leiteira.

\section{Introduction}

Dairy cattle breeding is practiced all over Brazil, with ranchers of diverse organizational and technological levels, among family farmers, small cooperatives, highly technological farms (Willers, Ferraz, \& Carvalho, 2014). This activity is highly important for the country, both in social and economic contexts.

Amazonian peasants are low-production itinerant growers who destroy their ecological habitat and have been threatened by extinction due to the advance of large landowners (stochastic frontier model). Such agricultural practice contrasts with the trend for a consolidated family farming, based on more complex production systems, including permanent crops, small animal husbandry, and livestock. This trend is more evident in northeaster Pará State but has also been statistically confirmed in the entire northern region of (Hurtienne, 2005). Among agricultural activities, dairy farming is essential for family farming development as income distribution promoter (Eurich, Weirich, \& Rocha, 2016), more than half $(58 \%)$ of the milk produced in Brazil comes from such farmers, which stand for $84.4 \%$ of all rural properties (Departamento Intersindical de Estatística e Estudos Socioeconômicos [DIEESE], 2011).

In livestock, reproductive management stands out as one of the key determinants for a good economic performance of the activity. In this sense, there are several factors that can interfere with reproduction rates. Besides animal reproduction, livestock profitability is also influenced by farm management, feed efficiency, and animal health due to lactation. In recent decades, genetic selection has been focused on increasing milk production to the detriment of reproductive traits (Norman, Wright, Hubbard, Miller, \& Hutchison, 2009). Among the most significant studies are those related to genetics, animal nutrition, and zootechnical management of herds (Junqueira \& Alfieri, 2006).

In the state of Acre, dairy activity is characterized by predominance of low technological farming, mainly in terms of animal nutrition, genetics, and reproduction (Andrade, Sá, Valentin, \& Cavalcante, 2011). Thus, according to Lopes et al. (2015b), 
several technical and managerial efforts are required to increase yield and profitability in this area.

Production conditions in each producing region must be featured by its potentials and needs (Battaglini, Fagnani, Dunga, \& Beloti, 2013). Milk production systems in the mesoregion of the Acre Valley should be characterized to identify their limitations and perspectives and to implement regional development plans, besides contributing to state public policies for the sector. In this sense, studies are needed to investigate the characteristics of the local family farms, and then develop programs aimed at strengthening possible weaknesses.

Cattle milk production generates jobs and income for many rural families in Western Amazon. Still, there are economic, technological, managerial, and professional qualification problems in production units that require consistent solutions. In this sense, our objective was to analyze 100 family dairy farms in the mesoregion of Acre Valley for some herd aspects at different milk production levels.

\section{Materials and Methods}

A survey was performed in 100 farms under family farming regime in the mesoregion of the Acre Valley, Western Amazon, Brazil. The study was carried out from March to June 2017. The studied area was composed of 14 municipalities with different number of ranchers: Acrelândia (6), Assis Brasil (3), Brasiléia (7), Bujari (4), Capixaba (8), Epitaciolândia (7), Manoel Urbano (4), Plácido de Castro (11), Porto Acre (6), Rio Branco (16), Santa Rosa dos Purus (5), Sena Madureira (12), Senador Guiomard (9), and Xapuri (2).

Dairy ranchers were randomly selected and interviewed in their farms (Gudkova et al., 2016). They were sorted out from lists provided by the State Secretariat of Agriculture (SEAP) and the Secretariat of Agroforestry Extension and Family Production of Acre State (SEAPROF), regardless of the marketed milk volume or adopted production system. The number of respondents was defined according to Barbetta (2003), considering a maximum sampling error of $5 \%$. For interview and diagnosis, a 248-question semi-structured form was used, following methods described by Foody (2003).

The questions were divided into the following topics: farmer and farm registration (52 questions), herd composition (12 questions), and milk production (184 questions). The latter includes production system, agricultural practices, nutritional management, infrastructure, zootechnical accounting, animal identification use, and reproductive management. Descriptive statistics were performed in the Exce ${ }^{\circledR}$ software, calculating average, standard deviation, median, interquartile range, and minimum and maximum values (Lopes et al., 2015a). SPSS 20.0 software (International Business Machines Corporation [IBM], 2011) was used to analyze the data from questionnaire surveys: production (total milk production per hectare per year), thus obtaining cohesive and liable results for analysis. Based on that, ranchers were divided into two clusters: "high production" $\left(1,755.65 \mathrm{~L} \mathrm{ha}^{-1}\right.$ $\left.\mathrm{yr}^{-1}\right)$ and "low production" (492,75 1,755.65 $\mathrm{L} \mathrm{ha}^{-1}$ $\left.\mathrm{yr}^{-1}\right)$, using the K-means non-hierarchical method (Hair, Black, Babin, Anderson, \& Tatham, 2009).

A multivariate cluster analysis allowed us to group farmers by similarity or dissimilarity based on one or more variables (Kaufman \& Rousseau, 1990). The Shapiro-Wilk normality test was used to evaluate the distribution of continuous variables, by which normal distribution and/or homoscedasticity were not detected. These variables were expressed as median and interquartile range (IQR), and multiple comparisons between high and low production clusters were made using the MannWhitney U-test (Maroco, 2010). Differences were deemed significant when $\mathrm{p}<0.05$. 


\section{Results and Discussion}

After characterizing the dairy farms, we could find out factors related to the management adopted in the mesoregion of Acre Valley, in production and reproductive terms. And these can help ranchers to identify the most critical points in their production systems.

High and low production clusters showed milk productions of $1,755.65 \mathrm{~L} \mathrm{ha}^{-1} \mathrm{yr}^{-1}$ and $492.75 \mathrm{~L} \mathrm{ha}^{-1}$ $\mathrm{yr}^{-1}$, respectively (Table 1). These findings are much lower than those found by Moraes et al. (2016) for family farmers in the state of Rio de Janeiro $\left(13,085.59 \mathrm{~L} \mathrm{ha}^{-1} \mathrm{yr}^{-1}\right)$. When considering daily volume, milk yields were 80.00 and $42.50 \mathrm{~L}^{\text {day }}{ }^{-1}$ in high- and low-production clusters, respectively (Table 1). Godinho, Soares, Bertipaglia, Carvalho and Dian (2005) observed higher volumes (699.25 $\mathrm{L} \mathrm{day}^{-1}$ ) in São João Batista do Glória MG (Brazil), while P. O. Lima, Duarte, Souza, Aquino and Oliveira (2009) noted lower values (42.33 $\mathrm{L} \mathrm{day}^{-1}$ ) in the state of Ceará State (Brazil).

Regarding days of lactation, yields were 6.10 and 5.00 $\mathrm{L} \mathrm{cow}^{-1}$ lactation day ${ }^{-1}$ in high- and lowproduction clusters, respectively (Table 1). These values are lower than those obtained in other states by: J. L. Parré, Bankuti and Zanmaria (2011) in southwestern Paraná (12.09 and 6.26 L cow ${ }^{-1}$ day $^{-1}$ in high- and low-production farms), Lopes et al. (2007) in Minas Gerais (7.20 L cow ${ }^{-1}$ day $\left.^{-1}\right)$, R. D. Santos et al. (2009) in southern Bahia (9.46 L cow $^{-1}$ day $^{-1}$ ), Moraes et al. (2016) in Rio de Janeiro (12.15 L cow ${ }^{-1}$ day $^{-1}$ ), and Battaglini et al. (2013) in the central region of Paraná $\left(6.04 \mathrm{~L} \mathrm{cow}^{-1}\right.$ day $\left.{ }^{1}\right)$. In turn, our findings are higher than those of $P$. O. Lima et al. (2009) in the state of Ceará (1.26 $\mathrm{L} \mathrm{cow}^{-1}$ day $\left.^{-1}\right)$. Oliveira, Figueiredo, Oliveira and Nasciff (2001) stated that milk yield per lactating cow has direct effect on dairy production and the most viable alternative to increase farm profitability is increasing animal production. Thus, our findings underline the need to implement technical assistance programs for the rural properties studied, differences are sharp among Brazilian regions. The milk production sector in Acre State currently has one of the worst production indexes countrywise (Instituto Brasileiro de Geografia e Estatística [IBGE], 2017). In the studied farms, such a scenario is directly related to several factors such as low technological level and absence of production chain structure.

Lopes et al. (2012) pointed out that many managerial and even technological efforts should be made to increase daily milk yield without increasing mean variable cost. According to the authors, an alternative is to increase production efficiency, that is, yield per cow, thus optimizing spending on labor, medicines, artificial insemination, fixed taxes, energy, among others.

With respect to number of lactating cows, highand low-production clusters had medians of 13.00 and 12.00, respectively (Table 1). Battaglini et al. (2013) found that for every 18.64 animals on small farms in the center of Paraná State, 7.46 were lactating. Nero, Viçosa and Pereira (2009), studying 60 farms in a region of Minas Gerais State, observed less than 15 lactating animals in 51 of the studied farms $(85.0 \%)$, between 16 and 30 animals in eight (13.3\%), and more than 30 lactating cows in one $(1.7 \%)$. The percentage of lactating cows is an important index to define productive capacity of the system. This, in turn, is influenced by herd management efficiency, as well as by food and nutrition improvements. Besides contributing to a reduction in the age of first calving, it also enables animals to express their genetic potential. As a result, the number of unproductive animals in a herd is reduced (M. F. Silva, Silva, Nascif, \& Gameiro, 2018). Table 2 shows the stratification of herd composition. 


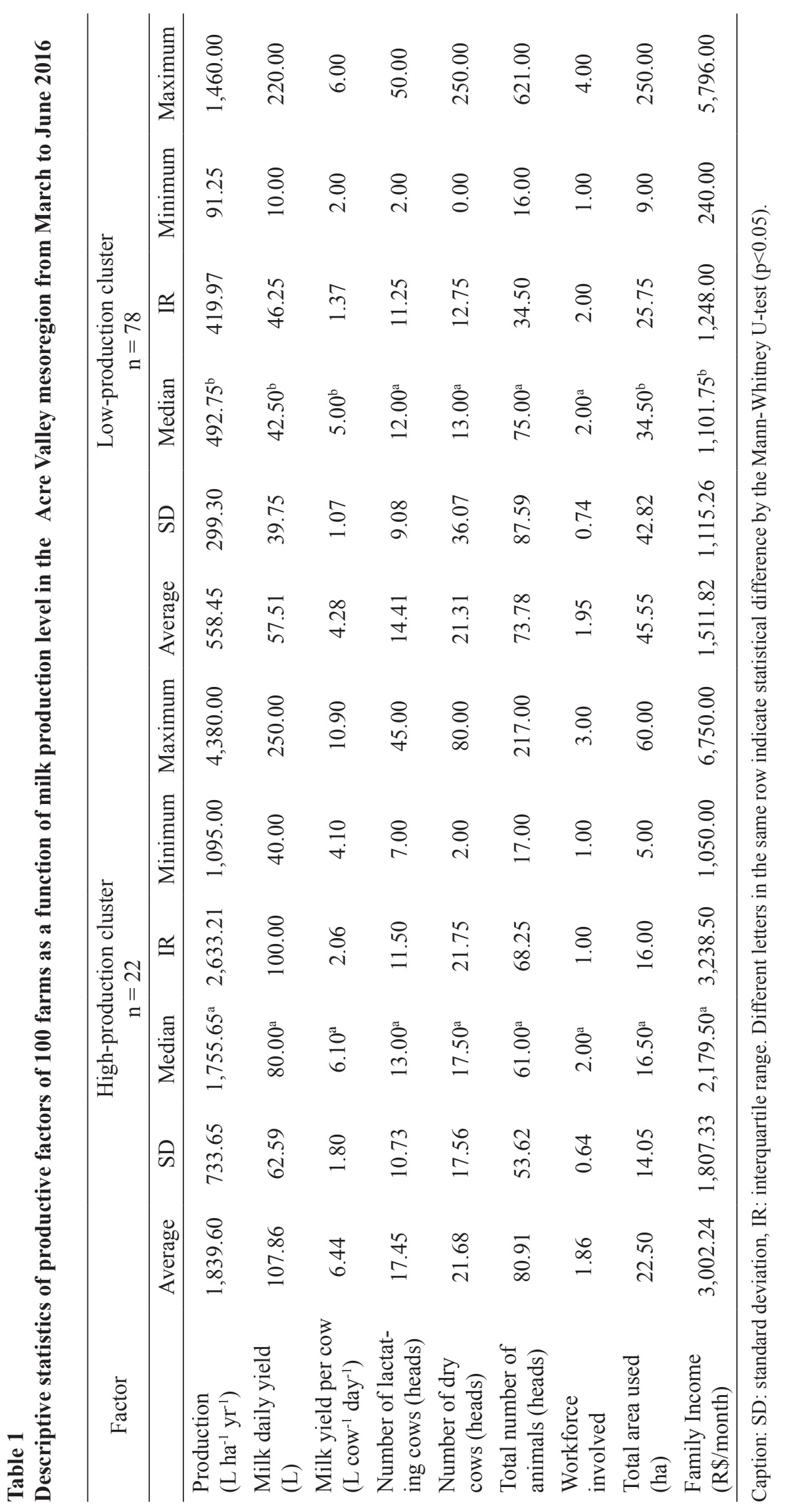

Semina: Ciências Agrárias, Londrina, v. 41, n. 5, suplemento 1, p. 2365-2380, 2020 
Table 2

Characterization of herd composition and production system of $\mathbf{1 0 0}$ farms studied as a function of milk production level in the Acre Valley mesoregion from March to June 2016

\begin{tabular}{|c|c|c|c|c|c|}
\hline \multirow[t]{2}{*}{ Factor } & \multirow{2}{*}{ Situation } & \multicolumn{2}{|c|}{$\begin{array}{l}\text { High-production } \\
\text { cluster }(\mathrm{n}=22)\end{array}$} & \multicolumn{2}{|c|}{$\begin{array}{l}\text { Low-production } \\
\text { cluster }(\mathrm{n}=78)\end{array}$} \\
\hline & & $\mathrm{n}$ & $\%$ & $\mathrm{n}$ & $\%$ \\
\hline \multirow{3}{*}{ Production system } & Pasture & 22 & 100.00 & 78 & 100.00 \\
\hline & Semi-confined & 0 & 0.00 & 0 & 0.00 \\
\hline & Confined & 0 & 0.00 & 0 & 0.00 \\
\hline \multirow{3}{*}{ Predominant breed } & NDB & 3 & 13.64 & 20 & 25.64 \\
\hline & Girolando & 19 & 86.36 & 57 & 73.08 \\
\hline & Dutch Belted & 0 & 0.00 & 1 & 1.28 \\
\hline \multirow{2}{*}{ Number of lactating cows (heads) } & Above or equal to 15 & 9 & 40.91 & 24 & 30.77 \\
\hline & Below 15 & 13 & 59.09 & 54 & 69.23 \\
\hline \multirow{2}{*}{ Number of dry cows (heads) } & Above or equal to 15 & 11 & 50.00 & 27 & 34.62 \\
\hline & Below 15 & 11 & 50.00 & 51 & 65.38 \\
\hline \multirow{3}{*}{$\begin{array}{l}\text { Total number of cows } \\
\text { (heads) }\end{array}$} & Above or equal to 50 & 16 & 72.73 & 41 & 52.56 \\
\hline & Below 50 & 6 & 27.27 & 37 & 47.44 \\
\hline & Ear tag & 10 & 45.45 & 25 & 32.05 \\
\hline \multirow[t]{3}{*}{ Cow identification system } & Branding iron & 3 & 13.64 & 8 & 10.26 \\
\hline & Name & 9 & 40.91 & 45 & 57.69 \\
\hline & None & 18 & 81.82 & 67 & 85.90 \\
\hline \multirow[t]{2}{*}{ Animal splitting system } & By lactation stage & 2 & 9.09 & 7 & 8.97 \\
\hline & By milk production & 2 & 9.09 & 4 & 5.13 \\
\hline \multirow{2}{*}{$\begin{array}{l}\text { Daily consumption of balanced ration } \\
\text { per lactating cow }\end{array}$} & None & 21 & 95.45 & 78 & 100.00 \\
\hline & Up to $1 \mathrm{~kg}$ & 1 & 4.55 & 0 & 0.00 \\
\hline \multirow{2}{*}{ Mineral salt supply } & Yes & 22 & 100.00 & 78 & 100.00 \\
\hline & No & 0 & 0.00 & 0 & 0.00 \\
\hline \multirow{3}{*}{ Suckling management } & Artificial with bottle & 0 & 0.00 & 0 & 0.00 \\
\hline & Artificial with bucket & 0 & 0.00 & 0 & 0.00 \\
\hline & Natural & 22 & 100.00 & 78 & 100.00 \\
\hline \multirow{3}{*}{ Water origin } & Headwaters & 3 & 13.64 & 4 & 5.13 \\
\hline & Dug reservoirs & 12 & 54.55 & 52 & 66.67 \\
\hline & Wells & 7 & 31.82 & 22 & 28.21 \\
\hline \multirow{2}{*}{ Drinking fountain } & Yes & 3 & 13.64 & 12 & 15.38 \\
\hline & No & 19 & 86.36 & 66 & 84.62 \\
\hline \multirow{2}{*}{ Electric fence use } & Yes & 13 & 59.09 & 33 & 42.31 \\
\hline & No & 9 & 40.91 & 45 & 57.69 \\
\hline
\end{tabular}


Fewer lactating animals together with low yields reduce production scale, which hence decreases farmer profitability. For Lopes et al. (2006), production scale influences total and operating costs and, therefore, profitability. Moreover, it is known that optimizing the physical structure of companies increases production scale to certain levels, with a reduced fixed cost per unit. In this context, Lopes, Santos, Resende, Carvalho and Cardoso (2011) and Demeu, Lopes, Costa, Rocha and Santos (2016) stated that, in most Brazilian states, a bonus is offered to milk producers based on the milk volume produced, and thus increasing their income.

Average herd composition was inadequate because high- and low-production clusters had only 17.45 and $14.41 \%$ of lactating cows, and $21.68 \%$ and $21.31 \%$ of dry cows, respectively (Table 1 ). These indices are well below the ideal composition of $42 \%$ of lactating cows and $8 \%$ of dry cows proposed by Campos \& Ferreira (2009). If the farmer has good planning and suitable herd composition, economic efficiency and income can be higher by sale of animals, what, for Lopes et al. (2011), can reach about $20 \%$. In sum, technicians and ranchers must be aware that the composition of dairy herds plays a fundamental role in the economic development of a rural property.

In terms of workforce, the studied farms showed a median of 2.00 for both clusters (Table 1). This is higher than those reported by Moraes et al. (2016) in Rio de Janeiro (1.42); and by Lopes et al. (2007) (1.44) and Ferrazza, Lopes, Moraes and Bruhn (2015), both in Minas Gerais. This parameter is important because, as daily milk production increases, labor productivity also increases (Bewley, Palmer, \& Jackson-Smith, 2001). Low production and number of lactating cows per worker contribute to the workforce idleness, with significant effects on production costs. In this sense, actions could be taken to increase workforce productivity, as follows: workforce training and specialization, and adoption of standard operating procedures and performance incentives (Stup, Hyde, \& Holden, 2006), as well as a business management focused on improving yield, allocating efficiency of production factors, and thus increasing production scale (Marques, Reis, Sáfadi, \& Reis, 2002).

In median, low-production cluster used a dairy production area (34.50 ha) 109\% larger than did high-production group (16.50 ha) (Table 1). As the latter produce more in a smaller area, these farmer may have had a more efficient land use (J. A. Santos, Vieira, \& Baptista, 2005), reducing representativeness of land remuneration (a fixed cost component) by use optimization (Lopes, Cardoso, Demeu, \& Dias, 2008), and hence increasing profitability of farmers.

In median, high-production cluster had a monthly family income of $\mathrm{R} \$ 2,179.50$, which is $97.47 \%$ higher than that of the low-production group (Table 1). This can be explained by the following parameters: lactating cow rate, milk liter per cow, and daily milk yield. It is worth mentioning that all these indexes are far below the ideal. Therefore, there is a clear need to improve them, which can be done by offering technical assistance to farmers. According to Nascimento and Pinto (2017), the absence of a technical monitoring often reduces farm productive potential, reducing yield, profitability, and competitiveness.

Table 1 displays the statistical analysis for quantitative parameters. Significant differences were observed between high- and low-production clusters for production $\left(\mathrm{L} \mathrm{ha}^{-1} \mathrm{yr}^{-1}\right)(\mathrm{p}=0.000)$, daily milk production (liters) $(\mathrm{p}=0.000)$, daily production per cow (liters) $(\mathrm{p}=0.000)$, total area for daily activity (ha) $(\mathrm{p}=0.001)$, and family income ( $\$$ /month) $(p=0.000)$. In short, there are several parameters that differentiate high and low production farms; therefore, it is believed that, if these parameters are well worked, profitability low-production farms can be increased.

All farms used a pasture production system. In the mesoregion of Acre Valley, dairy cattle are commonly reared in grazing systems to reduce costs, 
mainly due to the high cost of concentrated feed in the region. According to Stella, Stella and Gomes (2019), milk production at pasture is the most economical system. Conversely, Ervilha and Gomes (2017) stated that dairy production is economically attractive when production per area exceeds 4,576 milk liters per hectare per year, which was not achieved by any of the studied farms. To achieve this goal, pastures must have a satisfactory quantity and quality. F. A. P. Santos, Danés, Macedo and Chagas (2011) pointed out that dairy cattle production systems based only on tropical pastures does not meet the nutritional demand for high individual yields. In this sense, feed supplementation should be made to meet animal nutritional needs and be directly associated with economic income. This is because one of the reasons for the low use of concentrated foods by Brazilian cattle ranchers may be the lack of calculations about the efficiency of supplements (Teixeira et al., 2019)

Concerning cattle breeds, only one farm (1.24\%) in the low-production cluster reared Dutch Belted cattle; the others, 20 (25.64\%) and 57 (73.08\%), reared predominantly non-defined breeds (NDB) and Girolando, respectively (Table 2). The low production of dairy herds in Brazil is mainly due to two factors: poor reproductive performance and low genetic quality of animals, resulting in low lactation production, short lactation periods, and low persistence in production (Ferreira \& Teixeira, 2000).

Battaglini et al. (2013) highlighted that NDB and Girolando were the most observed in farms of central Paraná, with frequencies of $50.00 \%$ and $16.67 \%$, respectively, followed by Holstein and Girolando (6.86\%) and Girolando and Jersey $(4.90 \%)$ crossbreds. The same authors reported that the rates of purebreds were only $4.90 \%$ for Holstein and $1.96 \%$ for Jersey, and for other crossbreds totaled $14.71 \%$.

In terms of cattle identification, nine (40.91\%) and $45(57.69 \%)$ of the farms identified animals by name, and only $10(45.45 \%)$ and $25(32.05 \%)$ by ear tags, in the high- and low-production clusters, respectively (Table 2). For Lopes (1997), safe animal identification is basis for all management system functions, which result in zootechnical progress, besides production control and savings.

Most of the studied farms do not split lactating cows from the rest of the herd, $18(81.82 \%)$ and $67(85.90 \%)$ in high- and low-production clusters, respectively (Table 2). A herd management in grouped rearing is based on gathering animals as uniformly as possible in terms of size, age, production stage, and lactation and/or reproductive condition (G. S. L. Silva \& Silva, 2016). This is an important technique so that cows can be fed specific diets, which increases precision in reaching their nutritional requirements (Carrijo, Linhares, \& Barcelos, 2008). The general advantage is to meet the nutritional needs of different groups, reducing feed costs per animal per day, and being able to provide special supplements for each group (R. B. Reis, Souza, B. M. \& Oliveira, 2009).

Daily supply of a balanced feed for lactating cows was observed in only one farm $(4.55 \%)$ of the highproduction cluster (Table 2). Stelzer et al. (2009) highlighted that milk production increases by 3.8 $\mathrm{kg}$ with an increase in the ratio of concentrated feed in the diet. According to Deresz (2001), efficiency of supplementation with concentrates to dairy cows at pasture ranges from 0.50 to $0.90 \mathrm{~kg}$ milk per $\mathrm{kg}$ concentrate in the rainy season and from 0.80 to 0.95 in the dry season. Likewise, Vilela, Ferreira, Resende, Lima and Verneque (2007) reported that cows supplemented with 3 and $6 \mathrm{~kg}$ concentrate per day reached daily average yields of $15.5 \mathrm{~kg}$ and 19.1 $\mathrm{kg}$ milk, respectively, considering 330-day lactation period and higher lactation persistence. According to Bargo, Muller, Kolver and Delahoy (2003), when dairy cows at pasture are supplemented, forage dry matter intake usually decreases, which is known as replacement rate. It is worth highlighting that concentrated supplementations should be used rationally and economically to supply the correct 
balance of nutrients required by animals, which may not be met by only forage diets.

All farms supplied mineral salt (100\%) (Table 2 ). As carbohydrates and proteins, minerals are also important nutrients in animal diets (Wilde, 2006). Moreover, according to Lamb et al. (2008), minerals take part in several metabolic pathways and play important roles in reproduction, growth maintenance, energy metabolism, immune response, and other metabolic activities for a good productive performance.

In all the studied farms, calves were suckled naturally (Table 2). According to Van Amburgh and Drackley (2005), conventional suckling generally does not meet the nutritional requirements of dairy heifers for growth and development. Artificial suckling has provided suitable amounts of milk to calves in the first weeks of life, restricting to weaning and stimulating the best growth and adaptation to diets with roughages and concentrates (Virginio et al., 2016).

Absence of drinking fountains was a structural problem observed in $19(86.36 \%)$ and $66(84.62 \%)$ farms in the high and low production clusters, respectively (Table 2). Drinking fountains offer better quality water (cleaner and fresher) to cattle reared at pasture. According to cattle ingestion needs, animals must have free access to water, avoiding energy costs and hierarchical disputes. Therefore, the use of drinking fountains in pastures increases cattle yield (Tavares \& Benedetti, 2012). By contrast, in the majority of farms $(12,54.55 \%$; and $52,66,67 \%$ in the high- and low-production clusters, respectively), animals ingested water from large reservoirs dug in pastures during the dry period, which are fill up in the rainy season, the socalled "time of the waters". This process changes physical aspects of water such as temperature, color, and turbidity, besides its organoleptic properties (e.g., appearance, taste, and odor), which can make animals reject it for drinking purposes (World Health Organization [WHO], 1993). Dairy cattle require proper supply of good quality water for many organic functions such as rumen fermentation and metabolism, food-flow through digestive tract, digestion, nutrient absorption, blood volume, and tissue irrigation system (Nóbrega Neto, Araújo, \& Távora, 2016). Unfortunately, animal water intake has been often disregarded as a limiting factor to detriment of other dietary nutrients. However, low water intake increases hematocrit content and blood urea concentration, which reduces respiratory rate, rumen contractions, live weight, and milk production (L. Ribeiro \& Benedetti, 2011).

A limited water consumption reduces animal performance faster and more shortly than any other nutrient deficiency (Boyles, Wohlgemuth, \& Fisher, 1988). Cattle need constant and abundant supply of good quality clean water for regular rumen fermentation and metabolism, so that food flow could be maintained in digestive tract, favoring good digestion and nutrient absorption to supply body tissue demands (Adams \& Sharpe, 1995). Notwithstanding, water intake has direct impact on productive performance of cattle reared at pasture. According to Marino (2006), a bovine weighing $450 \mathrm{~kg}$ (1 UA) at an ambient temperature of $27^{\circ} \mathrm{C}$ consumes a water volume of $55 \mathrm{~L} \mathrm{day}^{-1}$. Moreover, Benedetti (2009) claimed that a minimum requirement is $45 \mathrm{~L} \mathrm{head}^{-1}$ day $^{-1}$ or about 8 to $9 \mathrm{~L}$ per $100 \mathrm{~kg}$ live weight, under proper management conditions.

The use of electric fence was reported in 13 $(59.09 \%)$ and $33(42.31 \%)$ farms of the high- and low-production clusters, respectively (Table 2). This technology helps reduce production system costs, increasing the efficiency and profit of dairy activities. In practice, cattle containment using electric fence properly can reduce up to $80 \%$ of the costs compared to barbed-wire fence (Torres, Machado, \& Mundim, 2007).

Pastures were considered regular in most farms, $11(50.00 \%)$ and $61(78.21 \%)$ in high- and lowproduction clusters, respectively (Table 3 ). However, 
it is important to point out that animal performance may be suboptimal in forage-based cattle feeding systems (Mesacasa et al., 2015). Grazing animals are known to be selective (Hodgson \& Brookes,
1999). So, in regular pastures (quality and quantity) as those in the studied farms, cattle diet may have affected voluntary consumption and hence dry matter intake.

Table 3

Characterization of zootechnical and reproductive factors of $\mathbf{1 0 0}$ farms studied as a function of milk production level in the Acre Valley mesoregion from March to June 2016

\begin{tabular}{cccccc}
\hline \multirow{2}{*}{ Factor } & & \multicolumn{2}{c}{ Cluster 1 $(\mathrm{n}=22)$} & \multicolumn{2}{c}{ Cluster 2 $(\mathrm{n}=78)$} \\
& Situation & High-production & \multicolumn{2}{c}{ Low-production } \\
\cline { 2 - 5 } & & $\mathrm{n}$ & $\%$ & $\mathrm{n}$ & $\%$ \\
\hline \multirow{3}{*}{ Pasture quality } & Optimal & 1 & 4.55 & 0 & 0.00 \\
& Good & 8 & 36.36 & 14 & 17.95 \\
& Regular & 11 & 50.00 & 61 & 78.21 \\
\multirow{3}{*}{ Pasture infested by weed } & Poor & 2 & 9.09 & 3 & 3.85 \\
\multirow{3}{*}{ Zootechnical bookkeeping } & Yes & 21 & 95.45 & 77 & 98.72 \\
& No & 1 & 4.55 & 1 & 1.28 \\
& Yes & 1 & 4.55 & 3 & 3.85 \\
Breeding system & No & 21 & 95.45 & 75 & 96.15 \\
& Natural mating & 20 & 90.91 & 72 & 92.31 \\
& Artificial insemination & 1 & 4.55 & 6 & 7.69 \\
& FTAI & 1 & 4.55 & 0 & 0.00 \\
Cow body condition at calving & Lean & 12 & 54.55 & 56 & 71.79 \\
& Average & 8 & 36.36 & 22 & 28.21 \\
& Fat & 2 & 9.09 & 0 & 0.00 \\
\hline
\end{tabular}

*FTAI: fixed time artificial insemination.

Presence of invasive plants was observed in pastures of $21(95.45 \%)$ and 77 (98.72\%) farms of the high- and low-production clusters, respectively (Table 3). Weed infestation does not occur in isolation but is an ecological response to crop management. Previous practices always have effect on weed population, so inadequate managements make desirable species less competitive to detriment of undesirable ones (Kemp \& King, 2001).

Zootechnical bookkeeping was not practiced in $21(95.45 \%)$ and $75(96.15 \%)$ of the farms in highand low-production clusters, respectively (Table 3 ). The main objective of this practice is to obtain extremely necessary information to plan, monitor, manage, and assist decision-making in any milk production system (E. M. B. Reis et al., 2019). J. N. Santos, Carvalho and Silva, (2006) stated that a barrier for increases in daily milk production and livestock breeding is the lack of information, hindering improvement of zootechnical indexes, which are the basis for a good management planning focused on livestock production effectiveness. For Lopes (1997), farm technological level, number of animals, among others are zootechnical records that can be made in simple notebooks or records of productive and reproductive control, or even 
in sophisticated computer systems. Despite being applicable, handwritten records are subject to errors and, therefore, not $100 \%$ reliable. When evaluating farms in the city of Ilhéus, Bahia state (Brazil), A. R. P. Ribeiro, Lobato and Abreu (2003) observed that zootechnical bookkeeping was done on a computer by $4.7 \%$ of the farmers, $34.1 \%$ used notebooks, and $54.1 \%$ made no record of herd situation. Similarly, Belchior (2001) reported that $62.0 \%$ of the farmers in the State of Minas Gerais did not make any type of herd record.

In regards to reproductive management, natural mating was used in 20 (90.91\%) and 72 (92.31\%) of the farmers in high- and low-production clusters, respectively (Table 3 ). This observation is similar to that reported by Clementino et al. (2015) in the state of Paraíba (99.10\%) and much higher than that of N. Lima, Pinto and Floss (2015) in the state of Paraná (48.18\%).

Animals showed low body condition score at calving in most of the farms, $12(54.55 \%)$ and 56 (71.79\%) in high- and low-production clusters, respectively. Body weight loss and negative energy balance at calving may negatively influence return to anestrus state and ovarian activity resumption in ewes (Mbayahaga, Mandiki, Bister, \& Paquay, 1998). Body score is a determining factor for faster endometrium recovery and heat manifestation, decreasing calving intervals (Barbosa et al., 2016) and hence increasing animal yield.

Since the production environment is dynamic, it is of practical interest to identify, quantify, and establish technical-managerial and zootechnical reference indexes, which should be considered by managers of rural companies and professionals who work with technical assistance and rural extension (Ferrazza et al., 2015).

\section{Conclusions}

High-production-cluster farms increased total milk production, milk yield per cow per day, and family income using a smaller area and less labor. They also had predominance of Girolando breed animals, higher quality pastures, and cows of better body condition at calving. Moreover, highproduction farms made more use of ear tags and technologies such as electric fence. Some of the productive factors found in the surveyed farms must be improved to enhance results and hence farmer profitability.

\section{Acknowledgements}

The authors would like to thank the institutions that collaborated for field activities, the Federal University of Acre, and the National Council for Scientific and Technological Development (CNPq).

\section{References}

Adams, R. S., \& Sharpe, W. E. (1995). Water intake and quality for dairy cattle. Pennsylvania, USA: Penn State Ext. Publ. Retrieved from http://www.das.psu. edu/research-extension/dairy/ nutrition/pdf/water. pdf

Andrade, C. M. S., Sá, C. P., Valentin, J., \& Cavalcante, F. A. (2014). Sistema de produção de leite a pasto no Acre. Rio Branco, AC: Empresa Brasileira de Pesquisa Agropecuária, EMBRAPA Acre.

Barbetta, P. A. (2003). Estatística aplicada às ciências sociais. Florianópolis, SC: Editora da UFSC.

Barbosa, L. P., Rodrigues, C. A. A., Guimarães, G. R., Torres, L. S., Carvalho, P. A., Amorim, M., \& Dutra, M. (2016). Influência da condição corporal ao parto no balanço energético e desempenho reprodutivo de cabras leiteiras no pós-parto. Arquivo Brasileiro de Medicina Veterinária e Zootecnia, 68(5), 1283-1291. doi: 10.1590/1678-4162-8371

Bargo, F., Muller, E. S., Kolver, J. E., \& Delahoy, J. (2003). Invited review: production and digestion of supplemented dairy cows on pasture. Journal of Dairy Science, 86(1), 1-42. doi: 10.3168/jds.S00220302(03)73581-4

Battaglini, A. P. P., Fagnani, K. S., Dunga, V., \& Beloti, R. (2013). Difusão de boas práticas e caracterização de propriedades leiteiras. Archivos de Zootecnia, 62(237), 151-154. doi: 10. 4321/S000405922013000100017 
Belchior, A. P. C. (2001). Prevalência, distribuição regional e fatores de risco da tuberculose bovina em Minas Gerais. Dissertação de mestrado. Universidade Federal de Minas Gerais, Minas Gerais, MG, Brasil.

Benedetti, E. (2009). Água na nutrição de ruminantes. In E. Benedetti (Ed.), Nutrição e alimentação de ruminantes (pp. 47-59). Uberaba, MG: Academic Press of FAZU.

Bewley, J., Palmer, R. W., \& Jackson-Smith, D. B. (2001). Modeling milk production and labor efficiency in modernized Wisconsin dairy herds. Journal of Dairy Science, 84(3), 705-716. doi: 10.3168/jds.S00220302(01)74525-0

Boyles, S., Wohlgemuth, K., \& Fisher, G. (1988). Livestock and water. Cidade: North Dakota State University, Extension Service Bulletin AS-954.

Campos, A. T., \& Ferreira, A. M. (2009). Composição do rebanho e sua importância no manejo. Juiz de Fora, MG: Empresa Brasileira de Pesquisa Agropecuária, EMBRAPA Gado de Leite.

Carrijo, M. S., Linhares, W. D., \& Barcelos, K. A. (2008). Descrição do manejo produtivo, reprodutivo e sanitário de 10 rebanhos leiteiros localizados em 7 municípios do estado de Goiás. PUBVET, 2(28), 279-294. Recuperado de http://www.pubvet.com.br/ texto.php?id=279

Clementino, I. J., Pimenta, C. L. R. M., Fernandes, L. G., Bezerra, C. S., Alves, C. J., Dias, R. A., \& Azevedo, S. S. (2015). Caracterização da pecuária bovina no Estado da Paraíba, Nordeste do Brasil. Semina: Ciências Agrárias, 36(1), 557-570. doi: 10.5433/1679-0359. 2015v36n1p557

Demeu, F. A., Lopes, M. A., Costa, G. M., Rocha, C. M. B. M., \& Santos, G. (2016). Efeito da produtividade diária de leite no impacto econômico da mastite em rebanhos bovinos. Boletim da Indústria Animal, 73(1), 53-61. doi: 10.17523/bia.v73n1p53

Departamento Intersindical de Estatística e Estudos Socioeconômicos (2011). Estatísticas do meio rural 2010-2011 (4a ed.). São Paulo, SP: DIEESE/NEAD/ MDA.

Deresz, F. (2001). Produção de leite de vacas mestiças Holandês x Zebu em pastagem de capim Elefante, manejada em sistema rotativo com e sem suplementação durante a época das chuvas. Revista Brasileira de Zootecnia, 30(1), 197-204. Recuperado de http://www.scielo.br/pdf/rbz/ v30n1/5453.pdf

Ervilha, G. T., \& Gomes, A. P. (2017). Efficiency and selection of benchmarks in milk production in
Minas Gerais - Brazil. Italian Review of Agricultural Economics, 72(2), 107-134. doi: 10. 13128/REA22657

Eurich, J., Weirich, P. H. W. Neto, Rocha, C. H. (2016). Pecuária leiteira em uma colônia de agricultores familiares no município de Palmeira, Paraná. Revista Ceres, 63(4), 454-460. doi: 10.1590/0034737X201663040004

Ferrazza, R. A., Lopes, M. A., Moraes, F. M., \& Bruhn, F. R. P. (2015). Índices de desempenho zootécnico e econômico de sistemas de produção de leite com diferentes níveis tecnológicos. Semina: Ciências Agrárias, 36(1), 485-496. doi: 10.5433/1679-0359.2015v36n1p485

Ferreira, A. M., \& Teixeira, N. M. (2000). Estimativas de mudanças na produção de leite pela variação no intervalo de partos de rebanhos leiteiros. Revista Brasileira de Reprodução Animal, 24(4), 177-181. Recuperado de http://cbra.org.br/br/publicacoes/ revista-brasileira-de-reproducao-animal/

Foody, W. (2003). Constructing questions for interviews and questionnaires theory and practice in social research cambridge. Cambridge, UK: University Press.

Godinho, R. F., Soares, V. E., Bertipaglia, L. M. A., Carvalho, R. C. R., \& Dian, P. H. M. (2012). Caracterização da produção leiteira em São João Batista do Glória (MG). Ciência et Praxis, 6(10), 1021. doi: Recuperado de http://revista.uemg.br/index. php/praxys/article/view/2106/ 1098

Gudkova, S., Cherepanova, N., Duplyakov, D., Golovina, G., Khokhlunov, S., Surkova, E.,... Shlyakhto, E. (2016). Lifetime prevalence of transient loss of consciousness in an urban Russian population. Arquivo Brasileiro de Cardiologia, 106(5), 382-388. doi: $10.5935 /$ abc. 20160056

Hair, F. J. Jr, Black, W. C., Babin, B. J., Anderson, R. E., \& Tatham, R. L. (2009). Análise multivariada de dados. Porto Alegre, RS: Bookman.

Hodgson, J., \& Brookes, I. M. (1999). Nutrition of grazing animals. In J. White \& J. Hodgson (Eds.), Parture and crop science (pp. 117). Auckland: Oxford University Press.

Hurtienne, T. (2005). Agricultura familiar e desenvolvimento rural sustentável na Amazônia. Novos Cadernos NAEA, 8(1), 19-71. doi: 10.5801/ ncn.v8i1.47

International Business Machines Corporation. Released (2011). IBM SPSS Statistics for Windows. Version 20.0. Armonk, NY: IBM Corp. 
Instituto Brasileiro de Geografia e Estatística (2017). Produção da pecuária municipal. Rio de Janeiro: IBGE. Recuperado de http://www.ibge.gov.br/home/ estatistica/economia/ppm/2015/ default.shtm

Junqueira, J. R., \& Alfieri, A. A. (2006). Falhas da reprodução na pecuária bovina de corte com ênfase para causas infecciosas. Semina: Ciências Agrárias, 27(2), 289-298. doi: 10.5433/1679-0359.2006v27n2p289

Kaufman, L., \& Rousseau, W. (1990). Finding groups in data: an introduction to cluster analysis. New York, NY: John Wiley \& Son.

Kemp, D. R., \& King, W. M. (2001). Plant competition in pastures: implications for management. In P. G. Tow \& A. Lazenby (Eds.), Competition and succession in pastures (pp. 85-102). New York, NY: CABI Publishing.

Lamb, G. C., Brown, D. R., Larson, J. E., Dahlen, C. R., Dilorenzo, N., Arthington, J. D., \& Dicostanzo A. (2008). Effect of organic or inorganic trace mineral supplementation on follicular response, ovulation, and embryo production in superovulated Angus heifers. Animal Reproduction Science, 106(3-4), 221-231. doi: 10.1016/j.anireprosci.2007.04.007

Lima, N. Jr., Pinto, A. Neto, \& Floss, F. (2015). Utilização da inseminação artificial (IA) e monta natural em rebanhos leiteiros no município de Realeza - PR: resultados parciais. Anais do Seminário de Ensino, Pesquisa e Extensão da Universidade Federal da Fronteira Sul, Realeza, PR, Brasil.

Lima, P. O., Duarte, L. S., Souza, A. Z. B., Aquino, T. M. F., \& Oliveira, C. S. (2009). Perfil dos produtores rurais do município de Quixeramobim no estado do Ceará. Revista Caatinga, 22(4), 255-259. Recuperado de https://periodicos.ufersa.edu.br/ index.php/caatinga/article/view/1389/ pdf

Lopes, M. A., Cardoso, M. G., Demeu, F. A., \& Dias, A. S. (2008). Composição de rebanhos bovinos leiteiros: levantamento, estimativa do dimensionamento e da evolução. Boletim de Indústria Animal, 65(2), 167-171. Recuperado de http://www.iz.sp.gov.br/ pdfsbia/1216213 983.pdf

Lopes, M. A., Lima, A. L. R., Carvalho, F. M., Reis, R. P., Santos, I. C., \& Saraiva, F. H. (2006). Efeito da escala de produção nos resultados econômicos de sistemas de produção de leite na região de Lavras (MG), um estudo multicascos. Boletim da Indústria Animal, 63(3), 177-188. Recuperado de http://www.iz.sp. gov.br/bia/index.php/bia/article/view/1263/1257
Lopes, M. A., Moraes, F., Carvalho, F. M., Peres, A. A. C., Bruhn, F. R. P., \& Reis, E. M. B. (2015a). Efeito do nível tecnológico na rentabilidade de sistemas de produção de leite participantes do programa "Balde Cheio": um estudo multicascos. Semina: Ciências Agrárias, 36(4), 2909-2922. doi: 10.5433/1679-0359.2015v36n4p2909

Lopes, M. A., Demeu, F. A., Rocha, C. M. B. M., Costa, G. M., Franco, A., Neto, \& Santos, G. (2012). Avaliação do impacto econômico da mastite em rebanhos bovinos leiteiros. Arquivos do Instituto Biológico, 79(4), 477-483. doi: 10.1590/S180816572012000400003

Lopes, M. A. (1997). Informática aplicada à bovinocultura. Jaboticabal, SP: FUNEP.

Lopes, M. A., Cardoso, M. G., Carvalho, F. M., Lima, A. L. R., Dias, A. S., \& Carmo, E. A. (2007). Efeito do tipo de sistema de criação nos resultados econômicos de sistemas de produção de leite na região de Lavras (MG) nos anos 2004 e 2005. Ciência Animal Brasileira, 8(3), 47-66. Recuperado de https://www. revistas.ufg.br/vet/article/view/1674

Lopes, M. A., Moraes, F., Carvalho, F. M., Peres, A. A. P., Bruhn, F. R. P., \& Reis, E. M. B. (2015b). Efeito de índices técnicos e gerenciais na rentabilidade da atividade leiteira com diferentes níveis tecnológicos. Revista Científica de Produção Animal, 17(2), 92102. doi: 10. 15528/2176-4158/rcpa.v17n2p92-102

Lopes, M. A., Santos, G., Resende, M. C., Carvalho, F. M., \& Cardoso, M. G. (2011) Estudo da rentabilidade de sistemas de produção de leite no município de Nazareno, MG. Ciência Animal Brasileira, 12(1), 77-91. doi: 10.5216/cab.v12i1.7725

Marino, C. T. (2006). Água na produção animal. Campo Grande, MS: Macal Nutrição Animal.

Maroco, J. (2010). Análise estatística com utilização do SPSS. Lisboa, PT: Sílabo.

Marques, V. M., Reis, R. P., Sáfadi, T., \& Reis, A. J. (2002) Custos e escala na pecuária leiteira: estudo de casos em Minas Gerais. Ciência e Agrotecnologia, 26(5), 1027-1034. Recuperado de http://www. editora.ufla.br/index.php/revistas/ciencia-eagrotecnologia/artigos-publicados/10-volumesrevista/62-vol26numero5

Mbayahaga, J., Mandiki, S. N. M., Bister, J. L., \& Paquay, R. (1998). Body weight, oestrous and ovarian activitiy in local Burundian ewes and goats after parturition in the dry season. Animal Reproduction Science, 51(4), 289-300. doi: 10.1016/s0378-4320(98)00063-3 
Mesacasa, A. C., Zervoudakis, J. T., HatamotoZervoudakis, L. K., Cabral, L. S., Abreu, J. G., \& Soares, J. Q. (2015). Torta de girassol em suplementos múltiplos para bovinos em pastejo no período seco do ano: parâmetros nutricionais. Semina: Ciências Agrárias, 36(3), 1559-1570. doi: 10.5433/1679-0359.2015v36n3p1559

Moraes, F., Lopes, M. A., Bruhn, F. R. P., Carvalho, F. M., Lima, A. L. R., \& Reis, E. M. B. (2016). Efeito de índices técnicos e gerenciais na rentabilidade da atividade leiteira com diferentes tipos de mão de obra. Archivos Latinoamericanos de Producción Animal, 24(1), 29-38. Recuperado de https://pdfs. semanticscholar.org/3bbe/c95933f6e6667dd1c1981 de0991712 066b13.pdf

Nascimento, V. A., \& Pinto, J. A. (2017). A importância da escrituração e avaliação dos indices zootécnicos em pequenas propriedades dos assentamentos Formiguinha, Pouso Alegre e Serra das Araras do munícipio de Mineiros. Anais do Colóquio Estadual de Pesquisa Multidisciplinar, Mineiros, $\mathrm{GO}$, Brasil, 1.

Nero, L. A., Viçosa, G. N., \& Pereira, F. V. (2009). Qualidade microbiológica do leite determinada por características de produção. Ciência e Tecnologia de Alimentos, 29(2), 386-390. Recuperado de http:// www.scielo.br/pdf/cta/v29n2/24.pdf

Nóbrega, S. B. N. Neto, Araújo, I. I. M., \& Távora, M. A. (2016). Qualidade de água de dessedentação de bovinos da fazenda-escola do IFRN-Ipanguaçu. Revista Holos, 32(3), 52-61. doi: 10.15628/ holos.2016.4150

Norman, H. D., Wright, J. R., Hubbard, S. M., Miller, R. H., \& Hutchison, J. L. (2009). Reproductive status of Holstein and Jersey cows in the United States. Journal of Dairy Science, 92(7), 3517-3528. doi: 10.3168/jds.2008-1768

Oliveira, T. B. A., Figueiredo, R. S., Oliveira, M. W., \& Nasciff, C. (2001). Índices técnicos e rentabilidade da pecuária leiteira. Scientia Agricola, 58(4), 687692. doi: 10.1590/S0103-90162001000400006

Parré, J. L., Bankuti, S. M. C., \& Zanmaria, N. A. (2011). Perfil socioeconômico de produtores de leite da região sudoeste do Paraná: um estudo a partir de diferentes níveis de produtividade. Revista de Economia e Agronegócio, 9(2), 275-300. doi: 10.25070/rea.v9i2.187

Reis, E. M. B., Lopes, M. A., Demeu, F. A., Bruhn, F. R. P., Lima, A. L. R., Benedicto, G. C., \& Pelegrino, D. F. (2019). Applicability of management tools to the correction of weaknesses in family dairy farms in the
Western Amazon. Semina: Ciências Agrárias, 40(1), 339-352. doi: 10.5433/1679-0359.2019v40n1p339

Reis, R. B., Souza, B. M., \& Oliveira, M. A. (2009). Sistemas de alimentação para vacas de alta produção. In P. C. Gonçalves, I. Borges \& P. D. S. Ferreira (Eds.), Alimentação de gado de leite (pp. 128-178). Belo Horizonte, MG: FEPMVZ.

Ribeiro, A. R. P., Lobato, F. C. F., \& Abreu, V. L. V. (2003). Aspectos da bovinocultura leiteira no Município de Ilhéus-BA. Arquivo Brasileiro de Medicina Veterinária e Zootecnia, 55(3), 119-122. doi: 10.1590/S0102-09352003000300021

Ribeiro, L., \& Benedetti, E. (2011). A importância da qualidade da água na nutrição de ruminantes. Cadernos de Pós-Graduação da FAZU, 2(1), 35-46. Recuperado de http:/www.fazu.br/ojs/ index.php/ posfazu/article/view/460/352

Santos, F. A. P., Danés, M. A. C., Macedo, F. L., \& Chagas, L. J. (2011). Manejo alimentar de vacas em lactação em pasto. Anais do Simpósio Sobre Bovinocultura Leiteira, Piracicaba, SP, Brasil.

Santos, J. A., Vieira, W. C., \& Baptista, A. J. M. S. (2005). Eficiência técnica em propriedades leiteiras da microrregião de Viçosa-MG: uma análise nãoparamétrica. Organizações Rurais Agroindustriais, 7(2), 162-172. doi: 10.22004/ag.econ

Santos, J. N., Carvalho, M. V. P., \& Silva, A. R. (2006). Escrituração zootécnica e registros de manejo, produção e reprodução de bovino leiteiros na região leste de Rondonópolis-MT. Anais do Congresso Brasileiro de Zootecnia, Recife, PE, Brasil, 16.

Santos, R. D., Pereira, L. G. R., Pereira, F. J. C., Neves, A. L. A., Brandão, L. G. N., Aragão, A. S. L., \& Araújo, G. G. L. (2009). Indicadores zootécnicos de unidades de produção de leite no sul da Bahia. Anais da Reunião Anual da Sociedade Brasileira de Zootecnia, Maringá, PR, Brasil, 47.

Silva, G. S. L., \& Silva, J. B. (2016). A importância da definição de um modelo de negócio na pecuária leiteira para a escolha da estratégia de comercialização. Revista de Administração do Sul do Pará (REASP), 3(2), 49-66. Recuperado de https://diadorim.ibict.br/ handle/1/782

Silva, M. F., Silva, A. C., Nascif, C., \& Gameiro, A. H. (2018). Interactions between technical and economic indicators for the efficiency analysis and management of dairy farms. Empreendedorismo, Gestão e Negócios, 7(7), 245-262. Recuperado de http://fatece.edu.br/ arquivos/arquivos\%20revistas/ empreendedorismo/volume7/24.pdf 
Stella, L., Stella, C. A., \& Gomes, B. C. K. (2019). Diagnóstico da produção de leite no município de Pejuçara-RS. Boletim da Indústria Animal, 76(1), 1-6. doi: 10.17523/bia.2019.v76.e1463

Stelzer, F. S., Lan, R. P., Campos, J. M., Mancio, A. B., Pereira, J. C., \& Lima, J. G. (2009). Desempenho de vacas leiteiras recebendo concentrado em diferentes níveis, associado ou não a própolis. Revista Brasileira de Zootecnia, 38(7), 1381-1389. doi: 10.1590/S1516-35982009000700030

Stup, R. E., Hyde, J., \& Holden L. A. (2006). Relationships between selected human resource management practices and dairy farm performance. Journal of Dairy Science, 89(3), 1116-1120. doi: 10.3168/jds. S0022-0302(06)72180-4

Tavares, J. E., \& Benedetti, E. (2012). Água: uso de bebedouros e sua influência na produção de bovinos em pasto. Cadernos de Pós-Graduação da FAZU, 2(8), 47-52. Recuperado de http://www.fazu.br/ ojs/ index.php/posfazu/article/viewFile/455/347

Teixeira, R. M. A., Martins, J. M., Silva, N. G., Silva, E. A., Fernandes, L. O., Oliveira, A. S.,... Farias, D. J. G. (2019) Protein supplementation of dairy cows grazing Tifton 85 during the dry season. Arquivo Brasileiro de Medicina Veterinária e Zootecnia, 71(3), 1027-1036. doi: 10. 1590/1678-4162-9805

Torres, R. A., Machado, J. R. C., \& Mundim, P. M. (2007). Estratégias de manejo e alimentação visando à melhoria da pecuária leiteira familiar das Regiões Sul e Centro-Sul Fluminense. Juiz de Fora, MG: Empresa Brasileira de Pesquisa Agropecuária: EMBRAPA Gado de Leite. Recuperado de https://www.embrapa. br/gado-de-leite/busca-de-publicacoes/-/publicacao/ 595365/estrategias-de-manejo-e-alimentacaovisando-a-melhoria-da-pecuaria-leiteira-familiardas-regioes-sul-e-centro-sul-fluminense
Van Amburgh, M., \& Drackley, J. (2005). Current perspectives on the energy and protein requirements of the pre-weaned calf. In P. C. Garnsworthy (Ed.), Calf and heifer rearing: principles of rearing the modern dairy heifer from calf to calving (pp. 67-82). Nottingham, UK: Nottingham University Press.

Vilela, D., Ferreira, A. M., Resende, J. C., Lima, J. A., \& Verneque, R. S. (2007). Efeito do concentrado no desempenho produtivo, reprodutivo e econômico de vacas da raça Holandesa em pastagem de Coastcross. Arquivo Brasileiro Medicina Veterinária e Zootecnia, 59(2), 443-450. doi: 10.1590/S010209352007000200026

Virginio, G. F. Jr., Azevedo, R. A., Ornelas, L. T., Oliveira, N. J., Geraseev, L. C., \& Duarte, E. R. (2016). Caracterização físico-química e microbiológica do fluido ruminal e do conteúdo gastrointestinal de bezerros holandeses em aleitamento artificial convencional ou fracionado. Acta Veterinaria Brasilica, 10(4), 305-313. Recuperado de https:// pdfs.semanticscholar.org/ a87e/10f3dd3ad5dc8c2b3 a6bcbe886d1414adede.pdf

Wilde, D. (2006). Influence of macro and micro minerals in the peri-parturient period on fertility in dairy cattle. Animal Reproduction Science, 96(3-4), 240249. doi: 10.1016/j.anireprosci.2006. 08.004

Willers, C. D., Ferraz, S. P., \& Carvalho, L. S. (2014). Determination of indirect water consumption and suggestions for cleaner production initiatives for the milk-producing sector in a Brazilian middle-sized dairy farming. Journal Clean Production, 72(1), 146-152. doi: 10.1016/j.jclepro. 2014.02.055

World Health Organization (1993). Guidelines for drinking-water quality (2nd ed.). Genebra: SWI, Geneva. 
